http://spilplus.journals.ac.za/

Ib/

TERUG NA TRAP DER JEUGD:

'N PRAKTYKBESKOUING VAN DIE RESULTAAT VAN TAALOPLEIDING

J. du T. McLachlan, Staatstaaldiens

\title{
1. Inleiding
}

Dit is so dat opleiding in die geesteswetenskappe nie altyd so beroeps- of praktykgerig as opleiding in ander dissiplines, bv. die geneeskunde of ingenieurswese, is nie. Dit is nietemin noodsaaklik dat die gegradueerde in die geesteswetenskappe meestal tog wel bepaalde praktiese vaardighede moet hê. As die ingenieur nie planne kan teken nie, as die geoloog nie alledaagse gesteentes kan uitken nie, as die instrumentmaker nie ' $n$ draaibank kan hanteer nie, het sy opleiding misluk. As die gegradueerde in sielkunde of maatskaplike werk ' $n$ gebrekkige kennis van elementère psigometriese toetsing of onderhoudvoering het, as die pas gekwalifiseerde onderwyser niks van onderrigtegnieke weet nie, as die geografiegegradueerde nie ' $n$ kaart kan lees nie, het sy opleiding misluk. En dus: as die taalgegradueerde nie basies korrek kan skryf nie, het ook sy opleiding misluk.

Dit help immers nie dat hy alles weet oor die jongste taalwetenskaplike teorieë en/of die letterkunde, maar hy kan nie die basiese "geneedskap van sy beroep", n], die taal, behoorlik hanteer nie.

As sulke tekortkominge wel bestaan, sal die praktiese of bercepsituasie nie beredder word deur die opleidingstandaarde te verlaag nie. Die opleiding moet inteendeel verbeter word. Dieselfde geld vir taalopleiding. 'n Mens durf eenvoudig nie sê dat die norme, standaarde en karaktertrekke van ' $n$ taal verlaag of aangepas moet word as dit eintlik die opleiding of onderrig in daardie taal is wat te kort skiet nie.

Die titel van hierdie referaat sinspeel daarop dat daar in taalopleiding opnuut aandag gegee moet word aan die basiese boustene van taalleer en die aanleer van taalvaardighede. Ons wil dus te kenne gee dat Die Taalwetenskap, ook in die rol wat hy te speel het in die opste van skoolkurrikulums en universiteitskursusse, sal moet toesien dat 'n sinvolle deel van taalkursusse weer gewy word aan dinge wat vroeër grotendeels deel uitgemaak het van die basiese leerboeke, die Trap der Jeugds.

Niemand verwag dat 'n student uit universiteit moet kom en alles moet weet nie. In my beroep word dit as vanselfsprekend aanvaar dat mense indiensopleiding moet kry ten einde ' $n$ gocie vertaler of redigeerder te kan word. Indiensopleiding of praktiese opleiding word 
egter ' $n$ onbegonne taak as ' $n$ mens moet begin met dinge wat die opleideling eintlik al teen die einde van sy skoolloopbaan onder die knie moes gehad het.

Taalgekwalifiseerdes is dus te gereeld onbevoeg om as taalwerker te begin werk ondat hulle kennis van grondliggende, benutbare taalleer skromelik te kort skiet. Die hoof van ons Engelse afdeling het dit só saamgevat: "Without a thorough knowledge of the basic 'bricks and mortar' of the language the average graduate is ill-equipped to deal with the practical application of the language."

Die huidige oorbeklemtoning van "taalwetenskaplik-teoretiese" aspekte van taalleer, "kommunikasjevaardighede" sonder die nodige formele grondslag, en letterkundestudie he gesamentlik daartoe gelei dat studente met allerlei taalkwalifikasies van universiteite veels te dikwels hoogs gekwalifiseerde taalbarbare is.

\section{Woordverklaring}

Met die oog op die res van die referaat wil ek vinnig sê wat ek bedoel met sekere terme wat ek gebruik. Met "taalpraktisyns" bedoel ek mense wat met hoofsaakjik geskrewe taal te doen het in 'n praktiese beroepsomgewing, soos vertalers en redigeerders, joemaliste, uitgewers, redakteurs en (taal)onderwysers. As ek praat van iemand met 'n "taalkwalifikasie", bedoel ek eenvoudig iemand op wie se graadsertifjkaat Afrikaans III, Engels II, Linguistiek III of iets dergeliks staan, want in die praktyk word daar selde na die inhoud van so 'n kursus gevra. Wanneer ' $n$ aanstellingsvereiste as sê maar Engels as hoofvak aangedui word, word daar slegs by hö̈ uitsondering gespesifiseer dat dit Letterkunde of Taalkunde of wat ook al moet wees. "Taalwetenskap" pord, soos die organiseerders aangedui het, inderdaad baie wyd geïnterpreteer en sluit enige vorm van wetenskaplike studie en onderrig van taalkunde in, ongeag die skool of model wat aangehang word. Voorts gebruik ek sekere terme wat seker beter in die tradisionele "outydse" taalkunde tuishoort, maar dit is terselfdertyd ook die terme wat in die taalpraktyk en skole nog ' $n$ werklikheid is.

Wat ek te sê het, geld in feitlik gelyke mate vir Afrikaans en Engels, en sekerlik ook vir die ander tale waarmee die Staatstaaldiens intern gemoeid is, veral Duits en Frans. 
http://spilplus.journals.ac.za/

159

\section{Basis waarop uitsprake berus}

Miskien klink dit wat ek ter inleiding gesê het, na wilde veralgemenings. Ten einde dit egter in perspektief te stel, te probeer sê op gesag waarvan ek sulke stellings maak, moet ek. $u$ eers ' $n$ kort agtergrond oor die Staatstaaldiens gee.

Die Staatstaaldiens staan reeds meer as sestig jaar lank in die taalpraktyk en kan dus seker as die "Senior Service" van taalkantore in die land beskou wond. Laat my direk byvoeg dat die Staatstaaldiens nie gemoeid is - altans nie regstreeks nie - met die soort amptenaretaal waarteen dese en gene so maklik te velde trek nie, dit wil sê met die daaglikse "interne" skryfwerk, korrespondensie en so meer van departemente nie. Die Staatstaaldiens kan eerder as die staat se publikasieredakteurs gesien word. Ons is dus hoofsaaklik gemoeid met die vertaling en taalkundige versorging van stukke - ongelukkig nie álle stukke nie wat op die een of ander wyse gepubliseer of aan die breë publiek blootgestel gaan word.

En om iets taalkundig gereed te kry vir publikasie, vereis nogal heelwat meer as om net - foute aan te merk! Daarbenewens maak ' $n$ taaladviesdiens ' $n$ baie belangrike deel van ons werk uit, 'n taak wat grotendeels per telefoon geskied.

Daar gaan gemiddeld meer as 20000 bladsye van 300 woorde elk per jaar deur ons hande en elkeen daarvan behels ten minste een van die twee amptelike tale. Senior beamptes van die Staatstaaldiens beantwoord gemiddeld bykans 8000 telefoonnavrae oor taalsake per jaar, wat wissel van spelling en grammatika tot stylkwessies en terminologie.

As u mooi dink waarby die staat alles op die een of ander wyse betrokke is, sal u besef dat ons werk velde en inhoud van die mees uiteenlopende aard dek, wat vanselfsprekend groot stilistiese, terminologiese en formuleringseise stel. Laat my vinnig 'n paar dinge noem waarmee ons gereeld in mindere of meerdere mate te doen kry:

* Politieke en vakkundige toesprake deur die Staatspresident, Kabinetslede en senior staatsamptenare.

* Ondergeskikte wetgewing, soos Goewermentskennisgewings, regulasies en proklamasies, waarin regstaal en uiters noukeurige taalgebruik uiteraard 'n kardinale rol speel.

* Verslae van kommissies en komitees van ondersoek en die Presidentsraad. Dink maar aan verslae soos dié oor inflasie, omgewingsbewaring, die Inligtingskandaal, die ineenstorting van AA Mutual Lewens, sekere beweerde moorde (Harms-verslag), psigopatie en pedofilie, ens. 
http://spilplus.journals.ac.za/

* Verslae van die SA Regskommissie, waarvan dié oor menseregte en grondwetlike modelle in die jongste tyd besonder baie publisiteit gekry het.

* Internasionale verdrae en ooreenkomste.

* Allerlei publikasies - algemeen en tegnies, wetenskaplik en populêr-wetenskaplik, formeel en minder formeel - cor, of in verband met, bv. landbou, bosbou, tuisteskepping, vigs, omgewingsaangeleenthede, besoedeling, veeartsenykunde, medisyne, oseanografie, wynbou, arbeidsaangeleenthede, gevangeniswese, bemarking, abattoirs, watervoorsiening. damveiligheid, plantkunde, geologie, brandbeveiliging, en noem maar op.

Kortom, daar is beswaarlik ' $n$ terrein van ons land se maatskaplike, ekonomiese en bedryfslewe wat ons nie die een of ander tyd taalkundig betree nie. Die mense met wie se taaluitinge ons te doen $\mathrm{kry}$, is dus nie net administratiewe personeel nie; dit sluit 'n baie groot komponent vakkundiges in, dikwels van die hoogs gekwalifiseerde mense op hulle terrein in die land. Dit sluit ook 'n toenemende getal skakel- en mediabeamptes in, van wie die meeste ook ' $n$ taal- of kommunikasiekundekwalifikasie het

Ten einde vir aanstelling in die Staatstaaldiens te kwalifiseer, moet iemand minstens ' $n$ driejarige B.-graad hê en in ons (ver)taaleksamen slaag. Hoewel die graad nie noodwendig 'n B.A. met tale hoef te wees nie, is dit slegs by uitsondering dat jemand wat nie ' $n$ taalkwalifikasie het nie, aansoek doen. In die jongste tyd het ook al hoe meer kandidate met of ' $n$ graad in vertaalkunde of ' $n$ nagraadse vertalersdiploma aansoek gedoen. Die meeste aansoekers kom van alle "blanke" Suid-Afrikaanse universiteite, Engels- sowel as Afrikaanstalig.

Die doel van hierdie bondige agtergrondsfeite met betrekking tot die Staatstaaldiens is om u 'n idee te gee van die basis waarop die stellings berus wat in hierdie referaat gemaak word Ons werk intensief met 'n geweldige hoeveelheid skriftelike materiaal wat stilisties én inhoudelik van hoogs uiteenlopende aard is. Ons behartig daagliks tientalle navrae oor algemene taalkwessies, navrae wat afkomstig is van oor die hele land, uit sowel die private as die openbare sektor. Ons het oor die jare honderde kandidate vir aanstelling by ons, die provinsiale taalkantore en die SA Weermag getcets. Die corgrote meerderheid van hierdie kandidate het 'n universitêre taalkwalifikasie op minstens tweedejaarsvlak, maar meestal op hoofvakvlak. Sedert daar aan universiteite vertalerskursusse ingestel is, kry ons aansoeke van ' $n$ beduidende aantal van die gegradueerdes met sulke kwalifikasies.

Dit sou dus nie ongeregverdig wees om te sê dat daar waarskynlik nie nog ' $n$ instansie is wat so "n omvattende oorsig oor die "stand van taalbedrewenheid in die land" het as die 
http://spilplus.journals.ac.za/

161

Staatstaaldiens nie. Die menings berus op ' $n$ besonder breë basis wat nie gebonde is aan enige spesifieke streek, provinsie, universiteit of amptelike taal nie.

\section{Uitgangspunt met betrekking tot norme en standaarde}

Die vraag na norme en standaarde tree natuurlik sterk op in gesprekke soos dié. Daar word in akademiese kringe baie gefilosofeer en geteoretiseer oor die kwessie van norme: Wat is norme eintlik? Wie stel die norme? Wie is bevoeg om nome te stel? Hoe gebiedend is norme? En so meer. Dit is natuurlik noodsaaklik dat daar oor dié dinge besin word, ook omdat dit op die ou end essensiële leiding kan gee aan die taalwerker wat in die praktyk staan.

In my beroep is daar egter nie veel ruimte vir bespiegeling oor sulke vrae nie. Ons word gewoon gekonfronteer met die werklikheid van norme, die feit dat daar norme is. Dié norme is vervat in woordeboeke soos die Oxford English Dictionary en die WAT en tientalle ander, in die talle taalgebruikershandleidings soos dié van Fowler, Partridge, Wood, Hiemstra, Spies \& Combrink, en Van der Merwe \& Ponelis, in taalhandboeke en grammatikas soos dié van Kempen, De Villiers, Quirk et al., om maar 'n paar bronne te noem.

Eweneens staan ons voor die werklikheid van algemeen-beskaafde of standaardtaal, hoe sosiopolities (en taalwetenskaplik?) ongewild sulke terme ook al vandag in Suid-Afrika is. Ons kan hierdie twee werklikhede nie ontken nie. Dit is ons taak om die norme en standaard van ten minste die twee amptelike tale te handhaaf - nie blindelings nie, maar cordeelkundig, omdat ons maar te bewus is van die voortdurende verandering wat in taal voorkom. 'n Houding van "enigiets sal deug" is egter net nie goed genoeg nie. Ons kliënte en die publiek laat dit gewoon ook nie toe nie, en $u$ as taalkundig geïnteresseerdes sal waarskynlik van die eerstes wees wat kritiek daarop sou lewer as ons eensydig van die norm sou afwyk. Bowendien sou allerhande afwykings van die standaardtaal regsimplikasies kon hẻ waaraan mens liefs nie eers wil dink nie.

Ons aanvaar dus dat norme verander, maar ons aanvaar eweneens die werklikheid van die bestaan van norme. Die feit dat 'n term 'n "boo-word" geword het vanweë die sosiopolitieke denke van die dag, of dat dit taalwetenskaplik as minder juis beskou word, doen nog nie afbreuk aan die werklikheid van die verskynsel nie. Om te sê dat die handhawing van die algemeen-beskaafde vorm van ' $n$ taal sommige sprekers van daardie taal benadeel ondat dit elitisties sou wees, is $\infty \mathrm{k}$ net 'n halwe waarheid. Dit iṣ moreel 
meer regverdigbaar om so ' $n$ persoon die algemeen-beskaafde of standaardvorm aan te leer, anders ontsê jy hom uiteindelik matskaplike vordering, maar veral toegang tot ' $t \mathfrak{n}$ enome korpus van bestaande literaturr wat in die standaardtaal geskryf is.

Prof. P.A.M. Seuren (7: 14), aangehaal in Onze Taal, sê byvoorbeeld: "Wie de jeugd leert dat reflectie op (de eigen) taal geen waarde heeft en dat men zich maar moet uiten, mondeling en schriftelijk, zoals men zich op elk gegeven moment 'voelt', creëert een kennisvacuüm... Bovendien bemoeilijkt men bij dialectsprekers de voor matschappelijk succes veelal beslist noodzakelijke aanpassing, in mondeling en schriftelijk taalgebruik, aan de standaardtaal." F.G. Droste (1: 46), ook in Onze Taal, sê: "... wie de staute pouw schrijft, is niet geschikt voor bepaalde maatschappelijke posities."

\section{Grondliggende leemtes}

In hierdie afdeling wil ek enkele grondliggende leemtes uitwys wat gereeld voorkom by gegradueerdes wat tot die taalpraktisynsberœep toetree of wil toetree. Die voorbeeide wat in die bylae verskyn, is eenvormigheidshalwe geneem uit dje eksamenskrifte van kandidate wat ons departementele (ver)taaltoets afgelè het. Die meeste van die kandidate het pas uit universiteit gekom, maar daar was ook talle wat byvoorbeeld in die onderwys gestaan het en van beroepsrigting wou verwissel - almal dus toetreders tot die beroep. Die voorbeelde is bloot ter wille van hulle illustrasiewaarde gekies, nie omdat hulle besonder swak of uitsonderlik is nie. Die skrywers het almal ' $n$ taalkwalifikasie op derdejaarsvlak of hoeer gehad. Van die foute kan weliswaar aan eksamendruk toegeskryf word, maar die tipe foute kom so gereeld en konsekwent voor dat die tendens nie geïgnoreer kan word nie.

\subsection{Spelling en skryfwyse}

Dit wil voorkom asof daar op skool nie meer van leerlinge verwag word om spelwoorde te leer nie en dat dit ook nie veel saak maak as hulle verkeerd spel nie. Hierdie neiging duur skynbaar op universiteit voort. Wie geeis, reenval, rieële, boerdery moontlikhede, huweliks ontbinding of mede passasiers, en chalenge, emosional, seperate, marrige of anounce skryf as hy 'n derdejaar-taalkwalifikasie het, se indiensopleiding, het die ondervinding geleer, $100 \mathrm{p}$ te dikwels op niks uit nie. (Terloops, die kandidate het verskeie vertalende en verklarende woordeboeke tot hulje beskikking warneer hulle die eksamen skryf.)

Ander algemene probleme is, by Afrikaans-kandidate, dat hulle nie die spelreëls kan toepas nie en, by Engels-kandidate, dat hulle nie tussen die spelvorme van werkwoorde en 
şelfstandige naamwoorde kan onderskei nie (bv. die advise $x$ advice-tipe gevalle) en ongelooflik baie klei trap by homofone, bv. councillor $\mathrm{x}$ counsellor, principle $\mathrm{x}$ principal, break $\mathrm{x}$ brake, compliment $\mathrm{x}$ complement, en so meer.

\subsection{Grammatika \\ 5.2.1 Woordsoorte}

Dit lyk asof 'n deeglike kennis van woordsoorte al hoe skaarser word. Dit skep natuurlik "kieelwat probleme in opleiding. Dink maar net hoe moeilik dit is om sekere Afrikaanse spelreëls duidelik te maak as die opleideling nie woordsoorte ken nie. Vandaar ook die probleem dat daar nie onderskei kan word tussen bywoorde en byvoeglike naamwoorde nie, soos in *oonwegende pastorale bevolking of *ekonomiese belangrike karakoelskape -

" ' 'n besonder algemene probleem. In Engels lei dit dikwels cok weer tot spelprobleme.

\subsubsection{Praktiese morfologie}

Wat Afrikaans betref, het die gebrekkige praktiese kenris van morfologie weer eens gevolge vir spelling (finansieel $\times$ finansiële $x^{*}$ finansieël/finansiëel) en skryfwyse (geëien $x$ toe-eien) en dit lei ook tot ' $n$ neiging om bywoorde alewig ' $n$-lik te wil gee, na die Engelse -ly. Dit hou cok verband met 'n onvermoe om bywoorde en byvoeglike naamwoorde te -onderskej, of om iets as byvoorbeeld ' $n$ meervoud te herken, soos in "'n kriteriala criteria of *a phenomena. In Engels lei voorts ook vervoeging tot probleme, bv. *occured i.p.v. occurred.

\subsubsection{Praktiese sintaksis}

Sinsbou en -ontleding is ' $n$ ernstige probleem. Onkunde daaroor lei tot groot probleme by punktuasie, sinsbetekenis, newe- en onderskikking en, veral in Engels, die keuse van die juiste werkwoondsvorm omdat skrywers byvoorbeeld nie die regte onderwerp kan bepaal nie. Ook kontinuering lewer baie probleme op, weer eens by die keuse van werkwoordsvorm, maar ook ten opsigte van antesedent en voomaamwoord. Sodra onderwerp en werkwoord of antesedent en voomaamwoord nie bymekaar staan nie, of sodra jets vanweë kontinuering weggelaat word, kan jy maar probleme verwag.

Prof. F.G. Droste (1: 47) sê hieroor: "We komen toe aan wat werkelijk belangrijk is: zinsbouw, argumentatieve structuur, verheldecing in plaats van verhulling." Met kennis van, of ocfening in, sinsbou en -ontleding sou sinne soos die volgende vermy kon geword het: "Toe ek aanvanklik ingestem het om ' $n$ referaat te lewer oor die moontlikheid om wildproduksie meer ekonomies te bedryf by hierdie kongres, het ek nie besef dat ..." en 
http://spilplus.journals.ac.za/

"Gedurende die afgelope jaar is sestien lewensredders deur haaie aargeval, waarvan yyf dood is."

Seuren (7: 14) veroordeel die mening dat "ontleden niet 'maatschappelijk relevant' (zou zijn), een theoretisch spelletje, zonder verder belang, dat voor sommige leerlingen te moeilijk is en daardoor meeheipt een maatschappelijke elite te vormen van diegenen die het wel kunnen. Ontleden was moeilijk, dus elitair, en dus verwerpelijk." Dan sê hy: "Verscheidene generaties schoolkinderen zijn op die manier opgegroeid zonder te hebben teren ontleden. Ze ondervinden daar nu de schade van." En ek wil daaraan toevoeg dat nie net die taalpraktyk nou die skade daarvan voel nie, maar wel die betrokke taal self ook.

\subsection{Norme}

Die kwessie van norme is vir die talpraktyk natuurlik besonder belangrik. Studente mœet seer seker met die teorie of filosofie van norme en standaarde kennis maak, maar dit is eweneens noodsaaklik dat daar ook na die praktiese sy van die kwessie gekyk word. Dit lyk my soms asof al wat ' $n$ akademiese talkundige is, sidder sodra ' $n$ mens van reëls in vorskriftelike sin praat, so asof dit die erfsonde of opperste kettery is. Daar is egter tog in elke taal dinge wat kan en nie kan nie, wat moet en nie moet nie. Dit is nog een van die ontwyfelbare werklikhede van die praktyk dat mense wil weet wat reg of verkeerd is, wat mag of nie mag nie - en dit help nie om te sê dat hulle nie so bchoort te dink nie, of dat hulle "taalfasciste" of so iets is nie. Die student moet ook hiervan deeglik kennis neem en moet weet waar om die norm, die reël as u wil, op te spoor en hoe om standaardbronne te gebruik en te interpreteer. Dit lyk soms asof studente so bewus gemaak word van die tekortkominge van byvoorbeeld woordeboeke dat hulle dit slegs baie huiwerig gebruik wanneer hulle in die praktyk kom. Nog 'n werklikheid van die praktyk is dat die brë publiek - en selfs geregshowe - standaardwoordeboeke as gesaghebbend en normatief beskou.

Dr. J. Renkema (6: 138), besturslid van die Genootschap Onze Taal, bevestig dit in 'n baie interessante artikel oor reëls en norme in taalgebruik, interessant omdat dit m.i. 'n baie gebalanseerde benadering het oor voorskryf en beskryf as dit by taalreëls kom en omdat dit terselfoentyd ' $n$ baie praktiese benadering is. Hy sê onder meer: "Maar vee' talgebruikers blijken vooral geïnteresseerd in wat mag of niet mag. ... In de taalwetenschap probeert men regels te formuleren waarmee taal en taalgebruik beschreven kunnen worden. Een taalkundige wil verklaren hoe taal in elkaar zit, en doet dit met behulp van regels. Maar wanneer een leek naar regels vraagt, bedoelt hij regels die aangeven hoe iets moet. Een leek heeft behoefte aan regels die vobrschrijven hoe men zich 


\section{http://spilplus.journals.ac.za/}

in saal uitdrukt. ... Zelfs als de taalkundige alleen een descriptie geeft, zien we dat een leek zo'n descriptie opvat als prescriptie." (my kursief)

\subsection{Taalsuiwerheid en idioom}

Hierdie aspek staan natuurlik in noue verband met die kwessie van norme en standaarde. Ek wil hier bekJemtoon dat ek van sowel Engels as Afrikaans praat, en dat dit nie gaan om 'n Angljsismejagtery nie. Die kwessie van suiwerheid en idioom kom veral ter sprake in kursusse soos Vertaalkunde, Toegepaste Linguistiek e.d., maar die fondament moet natuurlik in die "gewone" taalkursusse gelẽ word. Dr. Marian Labrum (2: 21), medeprofessor in Vertaalkunde en Spaans aan die Brigham Young-universiteit in die VSA, skryf die volgende hieroor: " $\ldots$ if he [die vertaler] allows the forn of the source language text to show up in the target language text ... then he has created what Alan Duff calls, 'a third language' ... To be a competent translator, one must be an expert in his own native language ..." (my kursief) Die hoof van ons afdeling Vreemde Tale het dieselfde gedagte só verwoord: "Die kandidaat is nie seker van sy eie taal nie en laat hom beïnvloed deur die brontaal; hy skryf dus 'n soort bastertaal of iets wat heeltemal onafrikaans of onengels is." Daar is genoeg voorbeelde in die bylae wat hierdie probleem baje duidelik illustreer.

Dieselfde beginsels geld natuurlik ook vir redigeerders, wat moet onthou dat iemand anders dalk die teks in ' $n$ vroeër stadium vertaal het of onder invloed van ' $n$ ander taal geskryf het. Hy moet dus eweneens die vermoë hê orn onsuiwerhede in die taal van die teks voor hom raak te sien en reg te stel.

Ek is deeglik bewus van hoe die twee amptelike tale in ons land mekaar oor die jare heen beïnvloed het (onder andere B.C. Donaldson het uitvoerig hieroor geskryf) en probeer dus nie sê dat byvoorbeeld Afrikaans moet terugkeer tot 'n soort Nederjands met 'n ander spelling of dat Engels in Suid-Afrika nou opsiuit alle Amerikanismes moet uitroei nie. Terselfdertyd is dit ook geen skande om die suiwerheid van die twee tale so ver moontlik te probeer handhaaf nie. Dit is ' $n$ werklikheid van die praktyk dat elke taal sy eie karakter en aard het. Nog 'n werklikheid van die praktyk: mense bly nou maar ten ene male sensitief, selfs jaloers, $\infty$ r hulle moedertaal. In die onlangse referendumveldtog het ' $n$ sekere party briewe aan kiesers uitgestuur, $\infty \mathrm{k}$ in Engels. Daar was maar ' $n$ paar eienaardighede in die Engelse teks, en geen dag of twee nadat die brief in my posbus beland het nie, was die eerste protesbriewe oor die taalgebruik in die koerante. 


\subsection{Taalvaardighede}

Baie aspekte van taalvaardighejd het natuurlik reeds ter sprake gekom onder ander opskrifte. Hier wil ek dus net weer die kwessie van stelvaardigheid noem, met ander woorde die vermoé om gedagtes logies en sinvol te formuleer. In enige van die beroepe wat ek vroeër in my omskrywing van "taalpraktisyn" genoem het, is hierdie vaardigheid essensieel. Dink maar hoe belangrik dit is dat 'n onderwyser eksamenvrae helder en duidelik formuleer; vir die joernalis is stelvaardigheid ' $n$ vanselfsprekende vereiste.

As ' $n$ taalgekwalifiseerde skryf dat ' $n$ land "' $n$ sanderige half-woestyn klimaat" het of praat van "die vestiging van rondirckkende nederseftings", het hy, benewens ander tekortkominge, nog nie leer dink oor wat hy skryf nje. Die antwoordstel van ' $n$ kandidaat met Afrikaans en Engels as hoof vakke en honneurs in Afrikaans, wie se dosent bowendien in 'n gloeiende getuigskrif gesê het dat hy veral beïndruk was met haar skriftelike werk, het gewemel van sinne soos die volgende: "Behalwe vir die ekonomiese belangrike karakoelskaap, wat gedy in die droë sujdelike streek, asook die gemiddelde beespopulasie, lewer die land as 'n geheel gemiddelde en onseker vooruitsigte wat betrek sy minerale bronne, veral diamante en kopper, kan die ekonomiese groei in 'n groot mate daaraan toegeskryf word." ' $n$ Voorbeeld uit die skrif van 'n kandidaat met Engels as hoofvak: "Moreover it is difficult to anticipate how any law people who find it intolerable to live together and who are determined to loosen the bonds that they have bound, in the profound and intimate relations that a marriage can keep together." Hierdie kandidaat se professor van Engels het ook in 'n getuigskrif gesê sy "command of English is well above average".

F.G. Droste (1: 47) reageer soos volg op soortgelyke Nederlandse sinne: "Maar [Droste se] zin (2) is toch begrijpelijk, ondanks de syntactische misser en de blunder in de spelling? Jawel, maar dat is het taalgebruik van mijn vierjarige kleinzoon ook. Die laat zijn zinnen half-afgemaakt, die herhaalt zichzelf, en schiet te kort in woordkeus."

Sinne soos dié wat ek aangehaal het, hoort nie by mense wat 'n hoofvak-taalkwalifikasie het nie. Dit is skrikwekkend, en vir my as ouer met kinders op skool sorgbarend, om te dink dat taalgekwalifiseerdes met súlke taalvaardighede in die onderwys losgelaat word. Hiér begin die bose kringloop reeds.

Bogenoemde is klaarblyklik probleme wat lê op die vlak van die basiese vermoë van mense met ' $n$ taalkwalifikasie om daardie taal te hanteer. Dit gaan dus nie hier primêr oor hulle vertaalvermő en die probleme daarrondom nie. 


\section{http://spilplus.journals.ac.za/}

167

\section{Wat die taalpraktyk van die taalwetenskap verlang}

\subsection{Groter praktykgerigtheid}

Dit is so dat studie in die geesteswetenskappe ' $n$ belangrike rol in die verruiming van die student se gees moet speel en dat dit nie primerr beroepsopleiding is nie. In my beroep is die volgende óók ' $n$ werklikheid van die praktyk: hoe rujmer die gees, hoe breēr die belangstelling en hoe groter die "algemene kennis", hoe groter is die kanse dat die betrokkene 'n suksesvolle taalpraktisyn sal word.

Onlangs is egter in Beeld (3: 9) berig dat geesteswetenskaplikes ' $n$ simposium in Pretoria gehou het om "die huidige krisis in die geesteswetenskappe" te bespreek. Die berig word so ingelei: "Met die groter wordende klem op 'nuttige' kennis en beroepsgerigte onderrig kom die rol van die geesteswetenskappe in ' $n$ toekomstige Suid-Afrika al hoe meer in die gedrang. Kan die land nog bekostig om kunstenaars, letterkundiges, filosowe en historici te subsidieer te midde van soveel ander knellende probleme? Sal 'n BA-graad in die toekoms bloot as 'n luukse beskou word?"

Die geesteswetenskaplikes het hierop allerlei diepsinnige antwoorde gegee, waamee ek ten volle akkoord gaan. Wat die taalwetenskap betref, wil ek egter te kenne gee dat die antwoord minstens ten dele daarin lê dat talkursusse weer sal moet aandag gee aan prakties benutbare taalkennis, sodat die student, wanneer hy gradueer, darem ten minste die basiese gereedskap wat hy in sy gekose beroep nodig het, korrek kan gebruik. En dat mense korrek wíl skryf en praat, ly geen twyfel nie. Vir my is die duisende navrae wat die Staatstaaldiens in dien verbande per jaar moet beantwoord, al genoeg bewys. Suid-Afrika kan dit bowendien deesdae eenvoudig nie meer bekostig, nóg finansieel nóg produktiwiteitsgewys, om mense ten duurste deur skool en universiteit te kry as hulle opleiding eintlik maar van voor af moet begin wanneer hulle tot ' $n$ beroep toetree nie. Hiermee wil ek hoegenaand nie die waarde en belangrikheid van suiwer akademiese studie en teorie afmaak nie; ek sê bloot dat die praktyk en die samelewing met reg kan verwag dat 'n taalgekwalifiseerde darem sy basiese gereedskap moet kan hanteer.

Die taalwetenskap mag nooit vergeet dat 'n student, nadat hy afgestudeer het, moet gaan werk, in ' $n$ beroep moet gaan staan nie. Hoeveel van die studente wat Taalwetenskap of Afrikaans of Engels as hoofvak gehad het, beland daarna in ' $n$ beroep, byvoorbeeld die van universiteitsdosent, waar hy hom sujwer aan die letterkunde of teoretiese taalwetenskap kan toewy? 'n Klein handjie vol. Die res moet op die een of ander manier "daar buite" met sy 
http://spilplus.journals.ac.za/

taalkwalifikasie sy brood gaan verdien, en in die meeste gevalle vereis dit ' $n$ praktiese toepassing van die kennis wat mense by ' $n$ taalgekwalifiseerde verwag.

Harry Obst (5: 1). Direkteur: Taaldiens van die VSA se Departement van Buitelandse Sake, spreek sentimente uit wat ons nie vet genoeg kan onderstreep nie: "Just as there are politicians who occasionally tell the truth, there are curriculum writers, particularly in schools of engineering, medicine and natural sciences, who design curriculums which are very much in tune with the demands of the real worid outside the university's walls. However, when we tum to the schools of languages and linguistics we rarely find curricula based on the realities and dcmands of the marketplace where students utimately are supposed to work." (my kursief) Waarop ek nog net 'n luide "Amen!" wil toevoeg.

\subsection{Onderrig}

Die Sunday Times (4: 13) het onlangs uit Londen berig dat Britse onderwysowerhede stappe wil doen om terug te keer tot die meer tradisionele onderrigmetodes, aangesien die liberale kindgesentreerde "kreatiewe" metodes skokkende resultate opgelewer het, soos "a sharp decline in reading standards". Die berig sê onder andere die volgende: "The Wise Men's report lends weight to the principle of a 'knowledge base' and dismisses 'trendy' methods. It says: 'First, there is a persistent and damaging belief that children should never be told things ...' ... The experts condemn ... the obsessive fear of anything that might be deemed 'elitist', which led to the needs of the most able children being neglected ..."

Asseblief dus, Taalwetenskap, sien toe dat kinders reeds van laerskooldae af 'n deeglike kennisbasis in hulle taalkursusse kry - daarop word alles verder tog gebaseer - al sou dit ook ' $n$ goeie skoot papegaaileerwerk behels. Ek onthou nog steeds die ritse vorsetsels wat ons in st. 7 vir ons (uitstekende!) Duits-onderwyser moes leer, asook moeilike Engelse spelwoorde wat ons met behulp van rympies gememoriseer het. Die onderwys is immers in sy wese 'n ondemokratiese, elitistiese proses: mense wat jets weet, dra kennis oor aan dié wat dit nog nie weet nie. En hierdie proses kan maar gerus, met die nodige aanpassings, voortgaan totdat ' $n$ student die universiteit verlaat. Dis nie sonde nie. Die probleem is natuurlik dat daar tans amper ' $n$ hele geslag onderwysers is wat sélf nie die kennis het om die leemtes wat ek vroeër genoem het, aan te vul nie. F.G. Droste (1: 46), hoogleraar in Algemene Taalwetenskap in Leuven, weer eens: "Maar is het dan niet zonde om kinderen jarenlang bezig te houden met dit soort gesystematiseerde patroontjes als ze inmiddels zoveel nuttiger dingen zouden kunnen doen? Nee, dat is niet het geval. Ze 
http://spilplus.journals.ac.za/

169

kunnen niets nuttigers doen dan goed leren spellen, spreken, denken in taal; en als daar enig abstract denken voor nodig is, is dat een goed ding." (my kursief)

Ons sal dus graag wil sien dat taalwetenskaplikes 'n positiewe rol speel in kurrikulumbeplanning vir taalonderrig op skool, sowel as in die opleiding van taalonderwysers. Slegs op hierdie wyse sal daar 'n einde gemaak kan word aan die jammerlik gebrekkige funksionele taalkennis van studente wat die universiteit met ' $n$ taalkwalifikasie verlaat. Die heel belangrikste werklikheid van die praktyk is dus: In die taalpraktyk is 'n deeglike funksionele taalkennis essensieel.

Ex het 'n paar senior kollegas gevra om kortliks neer te skryf hoe hulle taalkursusse sien of wat hulle graag daarin sou wou sien. Hier volg 'n paar van dié menings:

* "Basiese grammatika moet op skool al geleer word, maar dit moet op universiteit steeds aandag kry. Ook in letterkundekursusse moet korrekte taalgebruik ' $n$ vereiste wees. ... As 'n student elke jaar slaag, maar sy/haar taalgebruik is swak, dan moet daar tog 'n manier wees om te verhoed dat so 'n student die kursus voltooi en sy/haar graad ontvang. terwyl hy/sy nie or die taalvaardighede beskik wat in die praktyk van hom/haar verwag word nie."

* "What is required is a fundamental knowledge of the language. This should include all forms of the verb and how to use them. A thorough knowledge of analysis would also be a good idea. Spelling remains important..."

* $\quad$ "Most graduates who have majored in English have studied literature exclusively ... and lack knowledge of fundamental language issues. The situation is usually no better among graduates who have taken courses in linguistics, since these tend to be to theoretical to be of any use in the practical writing and editing of English. ... In brief, even those who pass the examination usually need considerable coaching in the basics of English; the knowledge of those who fail ranges from poor to pathetic. Clearly the problem should be addressed at both school and university level."

* $\quad 95 \%$ van die kandidate bewys dat hulle kennis van die vreemde taal veel te wense oorlaat. Op universiteit leer hulle net die taal van die letterkunde maar nie die algemene omgangstaal ... nie. Dieselfde geld vir hulle eie taal en hulle kan hulle nie in hul moedertaal uitdruk nie, selfs al verstaan hulle die vreemde taal. Minder klem op letterkunde, meer klem op funksionele taalgebruik."

Ek wil weer beklemtoon dat ons geensins die belangrikheid van taalwetenskaplike teorie en letterkunde onderskat of wil aantas nie. Ons pleit bloot vir groter balans tussen teorie. 
letterkunde en funksionele taalkennis. Dit kan verkry word deur 'n sinvolle deel van taalkursusse aan furksionele taalkunde af te staan, deur toepaslike selfstudie aan studente voor te skryf en deur te vereis dat alle skriftelike werk wat studente lewer, taalkundig aan 'n minimumstardaard voldoen.

Ek wil dus afsluit deur te sê dat al kan ek die taal van teoretici en literatore praat maar ek het nie die praktiese taalkennis nie, ek die spreekwoordelike stuk klinkende metaal en galmende simbaal geword het.

\section{BIBLIOGRAFIE}

1. Droste, Flip G. "De spraakmakende gemeente: pleidooi voor een normerende commissie" Onze Taal, No. 4, april 1989, p. 46.

2. Labrum, Marian B. "What everyone should know about translation" The ATA Chronicle., Vol. XX, No. 7, July 1991, p. 1.

3. Louw, Liesl "Het 'n BA-graad nog bestaansreg?" Beeld, 22 Februarie 1992, p. 9.

4. Naido, Charmain "Thumbs down for trendy schooling" Sunday Times, 26 January 1992, p. 13.

5. Obst, Harry "The ivory tower of Babel" The ATA Chronicle, Vol XX. No. 1, January 1991, p. 1.

6. Renkema, J. "De taaladviesdienst: over regeis en normen in taalgebruik" Onze Taal, No. 11 , november 1985 , p. 138.

7. Seuren, P.A.M. Filosofie van de taalwetenschappen, M. Nijhoff, Leiden, 1990, aangehaal in C. Kostelijk "Over ontleden en dialect" Onze Taal, No. 9. september 1991, p. 14.

BYLAE: VOORBEELDE

N.B. 1. Daar is NIE tikfoute in hierdie voorbeelde nie.

2. Die tipe foute kom te gereeld en te algemeen voor om deurgaans as skryffoute (glipse) beskou te word. Dit word bevestig deur die herhaling van foute in dieselfde eksamenskrif.

3. Kandidate het verskeie vertalende en verklarende woordcboeke tot hulle beskikking wanneer hulle skryf.

4. Alle voorbeelde kom uit die werk van kandidate met 'n taalkwalifikasic op minstens derdejaarsvlak. 
http://spilplus.journals.ac.za/

171

\section{Spelling en skryfwyse}

$\begin{array}{ll}\text { semi-woestyn karakter } & \text { advicer } \\ \text { verbruik items } & \text { adament } \\ \text { trek volke } & \text { counseller } \\ \text { trekkers volke } & \text { councilling } \\ \text { hoof oorweging } & \text { occured } \\ \text { huweliks onibinding beginsel } & \text { intensional } \\ \text { noordeliketuislande } & \text { existense } \\ \text { industriële- en landbou sektore } & \text { cumelative } \\ \text { te weeggebring } & \text { apparantly } \\ \text { lang termynbeleggings } & \text { breaks (i.p.v. brakes) } \\ \text { in teendeel } & \text { forsee } \\ \text { 'n tydlank } & \text { dissapeared } \\ \text { ingedagte hou } & \text { developement } \\ \text { droeë } & \text { procede } \\ \text { debateer } & \text { building-era } \\ \text { potensiele } & \text { powerrelationships } \\ \text { onmiddelik } & \text { trialseries } \\ \text { stasdardisering } & \text { married- and family life } \\ \text { nigeer } & \text { dubble } \\ \text { bevredegende } & \text { divorse } \\ \text { diamande } & \text { marnige/marraige } \\ \text { Romeins Hollandse reg } & \text { ballarce } \\ \text { monitêre } & \text { compulsary } \\ \text { Fursiture design and architecture complimented each other. } \\ \text { Others have to slam on breaks... }\end{array}$

Others have to slam on breaks..

\section{Grammatika}

\section{Woordsoorte en morfologie}

\begin{tabular}{|c|c|}
\hline $\begin{array}{l}\text { oostenrykse barokmeester wie ... } \\
\text { karakoel skape } \\
\text { die egteliede .... 'n egtelied } \\
\text { geondersteun } \\
\text { in kriteria } \\
\text { verkeerdelikhede } \\
\text { 'n } 8,3 \text { persent verhoging } \\
\text { beweegingloos } \\
\text { wuifing } \\
\text { spandabelerigheid } \\
\text { argitektuursfooie } \\
\text { egmate } \\
\text { semie-woestyn }\end{array}$ & $\begin{array}{l}\text { it's attitude } \\
\text { people who is } \\
\text { causes which motivates } \\
\text { seldomly } \\
\text { a criteria/criterea } \\
\text { discemable } \\
\text { occured } \\
\text { indifferents [indifference] }\end{array}$ \\
\hline
\end{tabular}

these deliberate careless people

die gemeenskap effektiewelik dien

\section{Sinsbou en punktuasie}

1. Alhoewel heelwat laer as vorige jare, moet dje groeikoers as bevredigend gesien word, veral gesien warneer die stand van sake wat feitlike volledige werkverskaffung heers in die ekonomie en die rampspoedige klimaatstoestande wammee die landbou sektor gedien 
moet wees. Hierdie ontwikkelingstempo, nietemin, is nie bereik sonder verlies in ons ekonie met betrekking tot sekere opsigte. (Hons.-Afr.)

2. Die vraag is nou of die prinsiep, wat algemeen na verwys word as "huweliksbreuk" prinsiep, in plaas van die "skuldig" prinsiep nie ' $n$ meer bevredigende kriterium vir die bepaling vir die werking van 'n egskeiding nie. (Hons.-Afr.)

3. Standaardisering is nog nie deur 'n uitvoerende instansie ten uitvoer gebring nie en kan die betrokkene dus nie van advies dien nie.

4. Alhoewel laer as in vorige jare, moet hierdie groei tempo nogtans as baje bevredegend beskou word. Veral as in gedagte gehou word, dat die ekonomie ' $n$ orvol arbeidsmark moet onderhou, en die swak klimaatstoestande wat probleme vir die landbou sektor veroorsaak het.

5. ... dat in die geval van bouplanne word die argiteksfooie nie betaal ...

6. As u nie die nodige stappe kan doen om die benodighede met ander te vervang nie, $u$ met die nodige middele voorsien sal word.

7. As individue geforseer kan word om sy medemens in ag te neem.

8 . ... maar besef dat selfs die mees vaardige bestuurder onder ons vorm ' $n$ gevaar vir die publiek agter die stuurwiel.

9. ... stappe wat geneem word vrugteloos sal wees as ...

10. Die land; met sy sanderige semi-woestyn klimaat, lae reënval en periodieke- en uitgerekte droogtes; het van die vroegste tye af ... (Hons.-Afr.)

11. Behalwe vir die ekonomies belangrike Karakoelskaap; wat floreer in die droè Suidelike gebiede; en 'n ... (Hons.-Afr.)

12. ... wat verband hou met skadevergoeding soos byvoorbeeld: diefstal.

13. ... wat gemaak kan word is dat ...

14. Aan sy minerale hulpbronne egter, inbesonder diamante en koper, is hy 'n groot mate van sy kragtige, ekonomiese groei verskuldig.

15. Na alles, in wat lê die sin, om 'n huwelik nietig te verklaar, op grond van die skuldgevoel van ' $n$ gade, wat sy eggenoot verlaat het, as daarby inderdaad die vryheid, aan hom, toegestaan word, wat hy tog duidelik wou hê?

16. Alhoewel laer as in vorige jare, moet die groeitempo nieteenstaande, as bevredigend beskou word, as gedagte gehou word, die toestande van feitlik ten volle werkverskaffing. wat behal is in die ekonomie en die ongunstige klimaats toestande waarmee die boere sektor te kampe het. Die tempo van ontwikkeling egter, was nie behaal sonder 'n prys van ons ekonomie op ander teryne nie.

17. Dit wil blyk, dat gedurende die eerste 6 maande van die jaar, 'n bevredigende tempo van uitbreiding weer behaal is, maar, dat die verhoging in dje prysvlak ietwat hoër was. 
http://șilplus.journals.ac.za/

18. Firstly there is a type of recklessness which seldomly goes to court as there has 18. already disappeared after he has been the cause of a collision to another.

19. The root of this evil lies not in the machinery which are given to loosen the cords that keep together a marriage, but in the various reasons that give cause to the disrupted relationships within the state of marriage.

20. Candidates, who dispose of the necessary qualifications, may apply ...

21. So did simplicity the distinctive characteristic of our Cape Dutch antiquities come into being.

22. ... the restraints that are binding them, rogether in the ... marriage.

23. Besides, it is difficult to foresee how any law could keep together people in the deat and intimate reiations of a marriage when they find it unbearable to live together, and who are determined to sever all ties.

24. Applicants must state their experience as teacher and must be accompanied by certified testimonials.

25. ... the race for results which make it impossible to .../ the rupture of relationships which make living together unendurable

26. ... people who find it untenable to live together and is determined to ...

27. Showy trifle and unnecessary panache was put aside.

28. ... what the ever changing position of numerous vehicles and circumstances were.

29. Has there been factors that ...?

30. If an applicant is unable to ... they must ...

31. Everyone who has had some difficulty in their lives ...

32. these type of incidents

\section{Taalsuiwerheid en idioom}

33. He has it against preoccupation with sports by which cultural and spiritual passessions is sometimes neglected.

34. It seems as if our means of proving them guilty in front of the court of justice are insufficient and inadequate.

35. We distance ourselves from ...

36. Others have to scream to a hait or use their breaks in order not to get into trouble.

37. Cape Holland(s) [architecture]

38. $\ldots$ to upraise him to a human in his own right,

39. This type of incident is far out of reach of human narration. 
40. Here is thought of those individuals who move to and fro among the moving traffic.

41. ... the survival of a nation is dependent on his state of mind and drive.

42. If someone must render a clear description of how a continuous changing position of certain vehicles and circumstances occured, would he know how impossible .... and would he also know that ... [NB nie 'n vraagsin nie]

43. ... and if we want to copy may we extract the good from ... [NB nie 'n vraagsin

45. some or other reason; in the rule; at own expense/cost/ costs; thus = Afr. "dus"

46. padverbruikers

47. In sulke tye is ... algemene sigte.

48. in betrekking met

49. Veronderstel ons aanvaar die stelling dat die meerderheid persentasie padgebruikers geen kwaadwillige bedoeling het nie, ...

50. ... die redelike beestroppe offer die land slegs beperkte landbou moontlikhede.

51. ... die gevolge van ons dade ..., of hulle nou van moedswilligheid, nalatigheid of net feilbaarheid ontspring.

52. Dit wil voorkom dat ... 'n bevredigende uitbreidingskoers weer bereik was.

53. ... dat geen verandering tot hierdie vertakking nodig is nie.

54. Dit word verder bevestig deur die besteding items wat na inflasionistiese ooruitgawe wys.

56. As daar enige pit steek in die idee van skadevergoeding eerder as straf as hoof oorweging, sal dit beteken dat enige stappe geneem waar daar nie sprake van skadevergoeding is nie, sinledig sal wees.

57. ... na gelang van die patroon van hulle aksies of hetsy gevaarpotensiaal ...

58. as 'n reel/reël; behalwe vir; by sulke tye; onder u sorteer; egskeiding en sy sosiale gevolge. 